УдК 355.48(=512.3):327(4)"12/13"

DOI: $10.22378 / 2313-6197.2017-5-3.509-521$

\title{
ECHOES OF THE CONFLICT BETWEEN TOKHTA AND NOGAI IN THE CHRISTIAN WORLD
}

\author{
Aleksandar Uzelac \\ The Institute of History Belgrade \\ Belgrade, Serbia \\ aleksandar.uzelac@iib.ac.rs
}

\begin{abstract}
Research objectives: The article is dedicated to the analysis of the echoes and reflections of the war (1297-1300) between khan Tokhta and his older cousin Nogai in the Christian West. Besides providing the general overview of the conflict, its political background, the course of the military operations and its geographic setting, the text deals with the various European and Christian contemporary sources referring to the internal struggles in the Golden Horde. Although these sources provide only the fragmentary notices about the conflict, they offer the possibility to critically assess how the Christian contemporaries looked upon the turbulent events in the Pontic Steppes, and to what extent they were familiar with them.

Research materials: Contemporary sources, mainly the texts written by the Byzantine historian George Pachymeres, Serbian archbishop Danilo II, Italian cleric Bartolomeo Fiadóni, his compatriot Franciscan John of Montecorvino, naturalized Frenchmen of Armenian origin Hayton (Het'um) of Corycos, as well as Venetian traveler Marco Polo.

Results and novelty of the research: The analysis of the sources shows that they share some common traits and refer to the turbulent events in the Golden Horde in similar manner, despite the different backgrounds of their authors. On the basis of their reports it may be concluded that the кеy events and the course of the war, as well as its consequences, were well known in the Balkans, and to a slightly lesser extent in the western Europe. Moreover, they reveal that the rumors about these events reached the remotest parts of the Christian world.
\end{abstract}

Keywords: Nogai, Tokhta, Christian world, Europe, George Pachymeres, Archbishop Danilo, Bartolomeo Fiadóni (Bartholomew of Lucca), Marco Polo, $13^{\text {th }}-14^{\text {th }}$ centuries

For citation: Uzelac A. Echoes of the Conflict between Tokhta and Nogai in the Christian World. Zolotoordynskoe obozrenie=Golden Horde Review. 2017. Vol. 5, no. 3, pp. 509-521. DOI: 10.22378/2313-6197.2017-5-3.509-521

The war between khan Tokhta (1291-1312) and his cousin Nogai, leader of the right wing of the Golden Horde, was undoubtedly the bloodiest and the most devastating conflict in the early history of the Juchids. Therefore, it is no surprise that the causes of this conflict that took place at the very end of the thirteenth century, as well as the course of the war and its consequences, were analyzed by a number of researchers $[3$, p. 177-184; 6, p. 131-141; 11, p. 65-71; 18, p. 246-253; 22 , p. $231-249 ; 28$, p. $157-163 ; 47$, p. $74-77 ; 51$, p. 88-98; 52, p. 185-189]. The source materials referring to the clashes between Tokhta and Nogai are relatively rich. Their conflict was described in detail in the voluminous chronicle of Mamluk writer Baybars al-Manșūī [5, p. 100-108, 111; 21, p. 110-119, 122-123] and also by Persian writer Rashīd al-Dīn Hamadān̄̄ [16, p. 84-87]. Some useful information is supplanted by several Arabic writers, among them Shihab al-Din al-Nuwayri [5, 
p. 128-132; 21, p. 158-162], and al-Muffadal [5, p. 153-154; 21, p, 195-196]; these events were also briefly recorded in Russian chronicles [12, p. 169, 172]. Finally, there are reports written by the contemporaries in the Christian Europe that include Byzantine, South Slavic, Latin and Old French texts. These sources provide only fragmentary picture of the conflict, but their value should not be underestimated. Namely, they offer the possibility to critically assess how the Christian contemporaries looked upon the turbulent events in the Pontic Steppes and to assess their attitude towards the Golden Horde.

Before we turn our attention to the echoes of the internal Juchid war, it is necessary to summarize its key points. The discord between the two leaders became apparent not long after Tokhta ascended to the throne of the Golden Horde in 1291, with the support of Nogai, who in the previous two decades gradually emerged as the most powerful regional lord in the Juchid lands. As early as in 1293/94, the two leaders lent their support to various, mutually conflicting political factions in the Russian lands. As a consequence of the punitive expedition against the prince Dmitry Alexandrovich led by his trustworthy general Tudan (Dyuden), Tokhta managed to suppress the influence of his cousin among the princes of the Nothern Rus' [3, p. 120-125; 4, p. 144-148; 13, p. 82-83; 14, p. 32; 16, p. 345-346]. It was a heavy blow for Nogai and it did not take long before his reaction ensued. Around 1296 he sent his sons to take control of the lands lying between Dnieper and Don and to extend his territory at the expense of the khan's possessions [16, p. 84-85]. Approximately at the same time Nogai's emissions of coins, bearing the attributes of the khan's power, and manifesting his formal independence from the Juchid ulus, appeared $[10$, p. $625-626 ; 14$, p. 35-36; 19, p. 76-79; 20, p. 17-19; 43, p. 245-258]. Soon, several prominent Tatar aristocrats abandoned Tokhta and joined Nogai, and when the latter blatantly rejected the khan's request to hand them over, the refusal served as the pretext of the war [5, p. 100;21, p. 110].

Until that moment it became obvious that the conflict would not be resolved peacefully. Both sides were prepared for the war that was about to take place. The two commanders gathered their forces and their armies met in the late 1297, probably on the banks of Aksay, backwater of the Lower Don [6, p. 134]. Although numerically inferior, Nogai's army managed to inflict a crushing blow to the enemy $[5$, p. 101, 129, 308; 21, p. 111, 159, 435-436]. However, the old leader was unwilling, or rather unable to exploit the victory on the battlefield to the full extent. Instead of pressing the enemy, he turned his attention to Crimea, in an attempt extinguish Tokhta's influence in the peninsula. It is possible that this Nogai's move was motivated by his alliance with Venice, who was at the simultaneous war with their traditional adversary Genoa, inclined to the khan.

Be that as it may, it turned out that Nogai's plans suffered an initial setback. His grandson was killed in the city of Caffa when he tried to collect the tribute from its citizens. Consequently, during the 1298, Nogai sent a punitive expedition to the peninsula and his forces took control of this port, and subjugated several other Crimean cities with force $[5$, p. 101, 153, 272-273; 21, p. 111-112, 195, 382]. Thus, Nogai managed to establish the control over the strategically vital region, but that success came with a price. Besides the exhaustion of his army, at that time the first signs of 
rupture appeared within it. Detachments, led by three sons of Tatar general Kurmishi, whose possessions lied on the right bank of the Lower Dnieper, rebelled against him. Their uprising was crushed in blood due to the joint efforts of three energetic Nogai's sons, but it did not stop the further scattering of his army [5, p. 101-102; 21, p. 112 113]. Soon, several of his commanders decided to switch sides in secret and to join Tokhta, allegedly with 30,000 men $[5$, p. $102 ; 17$, p. $85 ; 21$, p. 113]. The provided figures are doubtful, but their desertion evidently weakened Nogai's military power to a significant extent. Simoultaneously, the old commander tried in vain to secure the support of Ilkhanid ruler Gazan, but the khan of the Mongols in Persia was reluctant to meddle into the internal war between his distant cousins. Eventually, contrary to Nogai's expectations, he made a non-agression pact with Tokhta $[5, \mathrm{p} .153 ; 16, \mathrm{p}$. 86-87; 21, p. 196].

In such a way the khan managed to prevent the forming of potential coalition against him and the initiative passed into his hands. He again gathered his army, attaching to it also the detachments positioned in the Caucasian border, which guarded the passages towards Ilkhanid lands. In late 1299, he launched an attack deep within Nogai's territories. The opponent, aware of his numerical inferiority was forced to retreat, but he could not avoid the decisive battle. It probably took place on the banks of the river Cogîlnic (Kogylnik) in Moldova at the very end of 1299 or in early 1300 [17, p. 92; 26, p. 163; cf. 2. p. 356; 14, p. 36]. The outcome was Nogai's complete defeat. The old commander was slain by a Russian horseman from Tokhta's army, many of his men fell in the battle, and multitude was captured and later sold into slavery. However, Nogai's sons Chaka, Theka and Turai with minor part of their father's force managed to escape from the battlefield. Although only a fraction of once formidable Nogai's army survived the slaughter, the resistance and the struggle among the Juchids continued for two more years, before his sons disappeared from the historical stage and Tokhta finally succeeded to establish his control in the territories ruled by his deceased opponent. As a consequence of the war tribulations, hunger and mass emigrations of Nogai's subjects to the neighboring lands, the Pontic Steppes were depopulated to a high extent [5, p. $103-104,111 ; 6$, p. $141-147 ; 21$, p. $114-115,122 ; 28$, p. $259-263 ; 50$, p. $65-80$; 51, p. 91-98].

Many of the former Nogai's subjects and his comrades in arms found refuge in the Balkans. It was not a coincidence. During his turbulent career, Nogai managed to gradually build his sphere of influence in the region, and to establish himself as an undisputed arbiter in the mutual squabbles of the states in southeastern Europe. Initially, he meddled in the Balkan affairs in the capacity of a trustworthy ally of the Byzantine emperor Michael VIII Paleologos (1258-1282), whose illegitimate daughter Euphrosyne he married around 1273 [9, p. 124; 22, p. 138-139, cf. 50, p. 79]. The alliance lasted approximately a decade and during that time the Tatars proved to be of invaluable help in the Byzantine attempts to curb the threat from neighboring Bulgaria. After the death of his father-in-law, Nogai changed his approach. He became undisputed master of the Danube delta and he brought the Bulgarian lands, at the time divided between the two states - the Empire of Tarnovo and Principality of Vidin, under his control. Eventually, he also managed to obtain 
the acceptance of his suzerainty from Serbian king Stephen Uroš II Milutin (1293/94) [22, p. 219-224] It took place exactly at the time when the discord between him and Tokhta became apparent. Nogai's Tatars carried several attacks on the Byzantine possessions in Thrace in 1285, 1292 and finally in 1297, but the threat stopped only after the war in the steppes broke out [22, p. 195-198, 210 211, 225-226; 50, p. 80-88].

It may be argued that the most important source about the Byzantine relations with the Tatars of the Golden Horde is historical work of George Pachymeres (1242-1310). Highly educated man and holder of high public offices in Constantinople, he composed his 'Historical writings' at the end of the first decade of the fourteenth century [30, p. 77-82; 39, p. 288-291]. However, although Pachymeres dedicated his attention to the topics such as the establishment of Nogai in the Pontic steppes and internal conditions in the Golden Horde during the second half of the thirteenth century, the report about the internal war between the Juchids in his work is conspicuously short:

'[...] such were the conditions for a while, and Nogai was taking pride in his marital alliance with the emperor. After many [Tatars], who had the power by their birthright, were removed, only Tuctais [Tokhta] remained. He attacked Nogai, who was in old age. During the vigorous attack he overwhelmed him and Nogai was slain. A separate story is necessary, told in an extraordinary language, to tell all that had happened after that war, about the turmoil in that region, how the entire land was deserted and people put to death, and how those who were saved moved out from there and came here, as well as how the entire cargo on the ships was made of human beings' [31, p. 289-290].

Despite the fact that Pachymeres deliberately omitted to narrate the course of the war, there is no doubt that he was well informed about it. He had some information about the enthronement of Tokhta in 1291 and he was aware that Nogai was old, which is also mentioned by some oriental sources $[5$, p. 103, 129; 21, p. 114, 159-160], In the continuation of his work, the Byzantine writer dedicated more attention to Nogai's oldest son Chaka and his flight to Bulgaria, where he was eventually slain by his brother-in-law, Bulgarian ruler Theodore Svetoslav in 1301 [8, p. 27-33; 31, p. 289-290]. He also described in detail the migrations of a large group of sixteen thousand Alans, able-bodied men and their families, from Nogai's lands to Byzantiumc [31, p. 336-339]. Obviously, Pachymeres expressed stronger interest to the episodes that had direct influence and stronger importance for the Byzantine Empire than to the war itself.

No Bulgarian narratives of the era were preserved, but an important south Slavic text dealing with the war exists. Namely, the events are recorded in the life of Serbian king Stephen Uroš II Milutin (1282-1321), written by his contemporary archbishop Danilo II [23, p. 102]. Danilo's biography of the king was composed between 1324 and 1337, as part of the larger work - so-called 'Compendium of lives of Serbian kings and archbishops'. It contains important notices about the participation of Tatars in the events that shaped the destiny of the Balkans and Danubian region during the last decade of the thirteenth century, as seen from the perspective of the Serbian royal court. After Danilo described how king Milutin 
acknowledged Nogai's supremacy and sent his son and successor Stephen as a hostage to the Tatar leader [1, p. 120-122], he related how Milutin's son:

'[...]spent a lot of time in the court of unlawful Tatar Tsar Nogai. No one has told him to return to his fatherland, but good God, who cares for all of us, returned this young man unharmed to his father. After his departure a little time had passed, and the devil, unable to do any harm to the pious king [Milutin], wanted to be cheered by their deaths, and to look how they mutually devour themselves. Therefore, he aroused murdering hatred in them; one, who bore a powerful name among these Tatars, revolted with all his powers and came upon that wicked Tsar Nogai, who himself boasted against the state of the pious king. There was a great war between them and the bloodshed; he killed him [Nogai] with his own weapon and took his throne. Since then, a dissension among them [the Tatars] continued, and they began to exterminate themselves' [1, p. 122].

Similarly to Pachymeres, the Serbian writer was not concerned so much with the course of the war. He was more focused on the demise of Nogai, who was previously a formidable opponent of his king, and on the direct consequences of the conflict that led to the disappearance of the Tatar political influence in Serbian lands. The conclusion of his report reveals that he was undoubtedly familiar with the internal struggles that took place after the death of Nogai between his descendants. Considering the important role that Nogai played during his lifetime in southeast Europe, it is not surprising that the crisis in the Pontic steppes was closely followed in the Balkans and that the war sparked the interest of the local historians to record its outcome.

At first glance, it may seem that the chroniclers in western Europe skipped the internal conflict between the Juchids altogether. The reason for this did not lie in the lack of interest to the Chingisid world. Quite the contrary, around 1300, Roman Catholic world was full of hopes in the establishment of the alliance with the Ilkhanids, aimed at the reconquest of Jerusalem [45, p. 805-819], but in such a climate, unlike the affairs in Palestine, the events in the Golden Horde passed relatively unnoticed. There is, however, one notable exception. Among the western writers who dedicated their attention to the Mongol world was a disciple and confidant of St. Thomas Aquinas, named Bartolomeo Fiadóni, and better known as Bartholomew of Lucca or Tolomeo da Lucca (ca. 1236-1327). He wrote two important historical works - 'The Annals', written around 1308, and 'The New Church History', composed ca.1315. In both of them, Bartholomeo provided a short, but vivid description of the war between Nogai and Tokhta [46, p. 302-309]:

'In the year 1301 [sic!] one of the lords of the Tatars, the emperor named Theca [Tokhta], a good man who did many favors to the Christians, attacked the other, emperor Nocha [Nogai], who was the worst sorcerer and persecutor of all the good things, and destroyed him 
completely. And so, he became the lord in the North, Asia and in the eastern lands' [48, p. 237; 49, p. 646].

The year 1301 is obvious chronological mistake, but it may be easily explained, considering that the news about the Nogai's ultimate defeat and death in the Pontic Steppes probably reached western Europe with some delay. The more important is the author's positive view of the legitimate khan of the Golden Horde and open indignation towards his opponent. It undoubtedly reflects the stance of the influential circles of the Roman Catholic church. Despite the fact that Bartolomeo's source of the information is unknown, its origin may be suggested. Namely, it needs to be borne in mind that it was the Franciscan missionaries in Crimea and the Danube delta who served as the most trustworthy carriers of the news from the Golden Horde to the West. Both of the Juchid leaders had close contacts with the mendicants. At the height of his career, Nogai welcomed Franciscans in his lands and his chief wife Yaylak or Baylak-khatun (called Alakha by Pachymeres) was baptized by them during her stay in Crimea in 1286/87 [24, p. $193-199 ; 32$, p. $444-445 ; 39$, p. $157-162]$. In the beginning of the fourteenth century the activities of the Franciscan mission reached its apogee under Tokhta's patronage. Moreover, according to a letter of the Franciscans from Crimea in 1323, written a decade after the khan's death, he was so inclined towards the mendicants that he allegedly agreed to be baptized, or, according to their own words: '[...] the lately deceased Emperor [the khan] died a Christian, leaving behind him also three sons who were Christians' [33, p. 170-175; 35, p. 336-346; 45, p. 308].

There is no preserved Franciscan correspondence, directly related to the conflict between Tokhta and Nogai. It is, however, noteworthy that celebrated John of Montecorvino (1246-1328), the Franciscan who was ordained as the first Roman Catholic archbishop of Khanbaliq, made a striking reference to it. In one of his letters, sent to the pope in 1305, while discussing the routes from Europe to the Far East Montecorvino wrote:

'As to the road: I report that the way by the land of Cothay [Tokhta], the emperor of the Northern Tartars, is safer and more secure, so that, travelling with envoys, they might be able to arrive within five or six months. The other route is longer and more perilous since it involves two sea voyages [...], but the first mentioned route was not safe for a long time on account of the wars, and for twelve years I have not received news of the Roman Curia, and of our Order and of the state of the affairs in the West' $[29$, p. 226; 53, p. 349; 54, p. 48-49].

In another letter, written in the next year, Montecorvino mentioned that: '[...] a friend of ours, who was among the companions of the Lord Cothay [Tokhta] chan, came to the Lord chan of Cathay...' [29, p. 228; 53, p. 351; 54, p. 52]. These words reveal the hitherto unknown Montecorvino's informant about the Juchid affairs during his residence in China, and may serve as an important indication of the status of the Franciscans within the inner circles of the Juchid elite in Saray at the beginning of the fourteenth century. 
The notices about the events in the Golden Horde did not reach the West only through the missionary channels. There were other mediums of information, and other travelers and adventurers, experienced in the eastern affairs. Among them, the prominent place belongs to a noblemen and historian from Armenia Minor, named Hayton (Het'um) of Corycos, a member of Armenian royal house of Het'umids. At the end of the thirteenth century, he traveled to France where he stayed several years and joined Premonstratensian order. In 1307, while residing in Poitiers, Hayton dictated his famous work 'Flower of the Histories of the East' to his secretary Nicholas Faulcon, who wrote it in Old French, and simultaneously translated it into Latin. In his work, whose aim was to promote the FrankishMongol alliance in the Levant [7, p. 343-360; 27, p. 67-84], Hayton did not omit to discuss the internal conditions in the Golden Horde:

'Tochtay [in the French text Tocthaï], king of the Tatars, has his power in the realm of Komania, in the city of Sera [Saray]. He is able to gather 600,000 warriors. His men are not as brave as those of Chapar [Lord of the Chagataids, son of Khaidu], but they possess better horses. Sometimes they wage a war against the people of Carbanda [Öljaitü, ruler of the Ilkhanids, 1304-1316], sometimes against the Kingdom of Hungary, and sometimes they fight between themselves. Currently, Tochtay holds his dominion in peace' [36, p. 215, 335].

While Hayton left the recent events in the Pontic steppes on the margins of his work, except the allusion in the last two sentences of the quoted passage, it was another celebrated traveler, Venetian Marco Polo (1254-1324), who provided the most detailed account in the Christian world about the war between Nogai and Tokhta. It is presented in the final chapters of Polo's travels, dealing with the history of the Juchids and with the exception of the Tuscan redaction, composed in 1309 [41], it appears in most of its early manuscripts.

There is no need to underline here that this segment of Polo's text is not a proper historical account. Descriptions of several battles between the various factions in the Chingisid world, prominent in the Venetian's 'Travels' - those between khan Kublai and his opponent Naian, between Berke and Hülegü in the first Juchid-Ilkhanid conflict, as well as the first battle between Tokhta and Nogai were shaped according to the narratives present in the European literature of that era. It was much due to the influence of the Venetian's co-author, Rustichello da Pisa, writer of several chivalric romances, who shared the living quarters in the Genose Prison with Marco [34, p. 133-143; 38, p. 84-85; 44, p. 157-187].

Moreover, Polo's account of Juchid history is full of factual mistakes. According to him, khan Möngke Temür (1267-1282) was succeeded by Töle Bugha (1286/7-1291). Khan Töda Möngke (1282-1286/7), who in reality reigned between them, was, according to the Venetian, 'a very powerful man, who killed Tolobuga [Töle Bugha] with the evil help of another king of the Tartars whose name was Nogai... He reigned a while and not long; and then Totamongu [Töda Möngke] died, and Toctai who was a very wise and prudent man had the rule and was chosen for lord' $[25$, p. 402; 42, p. 483]. In addition to this conspicuous mis- 
take with respect to the relative chronology of the reigns of Juchid rulers, Marco Polo wrote that it was the two sons of Tolobuga, who wanted to avenge their father and asked Tokhta for help against Nogai, that provoked the war. The motive is, no need to emphasize, unhistorical.

Finally, it is important to note that the Venetian's account of the internal Juchid war is incomplete. It ends with the battle in which Nogai was triumphant. Being captured by the Genoese, probably in the battle of Kurzola (modern island of Korčula) in 1298, Polo did not know about its final outcome at the time when the earliest version of his 'Travels' was composed. Nonetheless, his account contains some valuable and intriguing information with respect to the place of the first battle between Nogai and Tokhta and the numbers of the engaged forces. According to the Venetian, the battle took place when 'both these kings came into this plain of Nerghi where they stopped for ten days so as to prepare themselves and to be fresh and rested on the day of the battle' $[25$, p. $405 ; 42$, p. 486; cf. 28, p. $252 ; 52$, p. 187-188]. As for the size of the armies, it is mentioned that 'the king Toctai made twenty battalions and put a good leader and good captain in each, and the king Nogai made fifteen battalions because in each he put 10.000 horsemen, and he put there a good captain and good leader' [25, p. 406; 42, p. 487]. These numbers are undoubtedly exaggerated, but they correspond to those provided by the oriental sources. According to Baybars al-Manșūī, Nogai had 200.000 horsemen, while Rashīd al-Dīn mentions that he had at his disposal 30 units of 10.000 men. Marco Polo (or his coauthor) also added a figure of 60.000 soldiers slain in the battle [25, p. 408; 42, p. 489]. The number is also just an invention, but oriental sources also record that the losses were great on both sides [5, p. 308; 21, p. 435-436].

Polo's account abruptly stops after the description of Nogai's victory. Subsequent events that led to the disaster of the old commander and his army, although not mentioned in the early versions of Polo's 'Travels', are described in the socalled Latin manuscript $Z$, written in the fifteenth century by an unknown hand and kept in Toledo [37, p. 456-463]. It is difficult to say whether its compiler relied on a written source when he added some of the following details, or just attempted to logically concluded Polo's narrative, but it is certain that demise of Nogai at the hands of his enemy was known to him:

'[...] in this action the king Toctai did not gather the whole force which he could, for he fully believed he would defeat Nogai with the people whom he had collected, since Nogai had come to the battle with one quarter fewer people than he. But yet, as you have heard, because the people of Nogai were more valiant and tried in the use of arms than the people of Toctai, so king Toctai succumbed in the battle and the conflict overwhelmed him. And therefore afterwards king Toctai gathered his whole force together and rose up manfully against king Nogai and defeated and killed him and his four sons [sic!], who were very valiant and tried men. And so vengeance was done for the death of Tolobuga' [25, p. 408; 42, p. 489]. 
The sources described and analyzed on the previous pages are all mutually independent, emerging from the various authors of different background. However, it is important to note that the Byzantine official, the Serbian Archbishop, the Italian cleric and Armenian and Venetian traveler, were contemporaries of the war between Nogai and Tokhta. All of them composed their works in the first decades of the fourteenth century and their accounts contain some striking parallels. Namely, the writers did not express interest in the origin of the conflict, or provided longer report about it, with the notable exception of Marco Polo (and Rustichello da Pisa). Archbishop Danilo and Bartolomeo Fiadóni, the writers who descended from the highest circles of Orthodox and Roman Catholic Church, expressed open enmity to Nogai, while Pachymeres and Marco Polo took more neutral stance. Unlike the authors in western Europe, the contemporaries in the Balkans were more familiar with the tragic consequences of the war that affected their lands - the depopulation of the Pontic Steppes, starvation and mass emigration of Nogai's former subjects. On the basis of these four texts, as well as allusions preserved in the writings of Montecorvino and Hayton the Armenian, it may be concluded that, despite the scanty notices preserved in the sources, the rumors about the internal struggles in the Golden Horde at the turn of the centuries were well known throughout Europe and that they reached the remotest parts of the Christian world.

\section{REFERENCES}

1. Arhiepiskop Danilo i drugi. Životi kraljeva i arhiepiskopa srpskih [Lives of Serbian Kings and Archbishops]. Ed. Đ. Daničić. Zagreb, Svetozar Galc, 1866 (reprinted by Variorum reprints, London, 1972). 386 p. (In Serbian)

2. Brun F. Chernomor'e - Sbornik issledovanij po istoricheskoj geografii Juzhnoj Rossii [The Black Sea Region - The Collection of the Researches about the Historical Geography of Southern Russia]. Odessa, Typography of G. Ulrich, 1880. 408 p. (In Russian)

3. Veselovskiy N.I. Trudy po istorii Zolotoy Ordy [Works on the History of the Golden Horde]. Kazan, Sh.Marjani Institute of History of Tatarstan Academy of Sciences Publ., 2010. 191 p. (In Russian)

4. Gorskiy A.A. Nogay i Rus' [Noghai and Rus']. Tyurkologicheskiy sbornik 2001 Zolotaya Orda i ee nasledie [Turcological Collection 2001 - the Golden Horde and Its Legacy]. Moscow, Vostochnaya literatura Publ., 2002, pp. 130-156. (In Russian)

5. Istoriya Kazakhstana $v$ arabskikh istochnikakh. Vol. 1: Sbornik materialov, otnosyashchikhsya $k$ istorii Zolotoy Ordy. Izvlecheniya iz arabskikh sochineniy sobrannye V.G. Tizengauzenom, per. i dop. izdanie [History of Kazakhstan in Arabic Sources. Vol. 1: The Collection of Materials Related to the History of the Golden Horde. Excerpts from Arabic sources collected by V.G. Tizangauzen, revised and updated edition]. Eds. B.E. Kumekov, A.I. Muminov. Almaty, Dayk Press, 2005. 711 p. (In Russian)

6. Mys'kov E.P. Politicheskaya istoriya Zolotoy Ordy (1236-1313 gg.) [Political History of the Golden Horde (1236-1313)]. Volgograd, Volgograd State Universitet Publ., 2000. 175 p. (In Russian)

7. Nikolov A. „Vjarvaj ili shhe te ubija” - „Orientalcite” v kr\#stonosnata propaganda 1270-1370 g. ['Believe or I Will Kill You' - 'Orientals' in the Crusading Propaganda 1270-1370]. Sofia, Sofia University 'St. Kliment Ohridski', 2006. 504 p. (In Bulgarian) 
8. Pavlov P. Patriarh Yoakim III, tatarskiyat khan Chaka i tsar Teodor Svetoslav [Patriarch Joachim III, Tatar Khan Chaka and Emperor Theodore Svetoslav]. Duhovna kultura [Spiritual Culture], 1992, no. 6, pp. 27-33. (In Bulgarian)

9. Pavlov P. Tatarite na Nogaj, B'lgarija i Vizantija (okolo 1270-1302 g.) [Nogai's Tatars, Bulgaria and Byzantium (around 1270-1302)]. B'lgarite v Severnoto Prichernomorie [Bulgarians in Nothern Black Sea Coast], IV, Veliko T'rnovo, 1995, pp. 121-130. (In Bulgarian)

10. Petrov P. Den'gy y denezhnaja polytyka Dzhuchydov v XIII-XV vv. [Coins and Monetary Policy of the Juchids in the $13^{\text {th }}-15^{\text {th }}$ Century]. Zolotaja orda v mirovoj istorii [The Golden Horde in World History], eds. R. Khakimov and M. Faveraeu, Kazan, Sh.Marjani Institute of History of Tatarstan Academy of Sciences Publ., 2016, pp. 616633. (In Russian)

11. Pochekaev R.Yu. Tsari ordynskie: Biografii khanov i praviteley Zolotoy Ordy [Emperors of the Horde: Biographies of Khans and Rulers of the Golden Horde]. St. Petersburg, Evraziya Publ., 2010. 408 p. (In Russian)

12. Polnoe sobranie russkih letopisej, T. X: Letopisnyj sbornik, imenuemyj Patriarshej ili Nikonovskoj letopisi (1177-1362) [A Complete Collection of the Russian Chronicles, Vol. X: A Chronicle named Patriarchical or Niconian Chronicle]. St. Petersburg, Typography of the Department of Internal Affairs, 1885. 244 p. (In Russian)

13. Polnoe sobranie russkih letopisej, T. XVIII: Simonovskaja letopis' [A Complete Collection of the Russian Chronicles, Vol. XVIII: Simeonian Chronicle]. Ed. A. Koshelev, Moscow, Znak Publ. 316 p. (In Russian)

14. Porsin A.A. Nogaj i ego rol' v politicheskoj zhizni Zolotoj Ordy v 90-e gody XIII veka [Nogai and His Role in the Political Life of the Golden Horde in the 1290s]. Zolotoordynskaja civilizacija [Golden Horde Civilization]. Kazan, Sh.Marjani Institute of History of Tatarstan Academy of Sciences Publ., 2014, no. 6, pp. 29-40. (In Russian)

15. Priselkov M.D. Troickaja letopis'. Rekonstrukcija teksta [Troitskaja Chronicle. Reconstruction of the Text]. Moscow, Leningrad, 1950. 512 p. (In Russian)

16. Rashid al-Din Fazlallah. Sbornik letopisey [Compendium of Chronicles], Vol. 2. Eds. Yu.P. Verhovskij, B.I. Pankratov. Moscow, Leningrad, Akademiya Nauk SSSR Publ., 1960. 214 p. (In Russian)

17. Russev N.D. Zolotaja Orda na nizhnem Dunae [The Golden Horde on the Lower Danube]. Zolotoordinskaja civilizacija [Golden Horde Civilization]. Kazan, Sh.Marjani Institute of History of Tatarstan Academy of Sciences Publ., 2009, no. 2, pp. 90-103. (In Russian)

18. Sabitov Zh. Voennoe protivostoyanie Nogaya i hana Tokty [Military Confrontation between Noghai and Khan Tokhta]. Voennoe delo Ulusa Dzhuchi i ego naslednikovsbornik nauchnyh statey [Warfare of the Ulus of Juchi and Its Successors - Collection of Scientific Papers]. Astana, Foliant Publ., 2012, pp. 246-253. (In Russian)

19. Severova M.B. I snova o monete s imenem Nogaya, a takzhe o redkoy krymskoy monete s dvumya tamgami [Again on coin bearing Noghai's name and also on rare Crimean coin with two tamghas]. Desyataya Vserossiyskaya Numizmaticheskaya konferentsiya, Pskov, 15-20 aprelya 2002 g. Tezisy dokladov i soobshcheniy [Tenth All-Russian Numismatic Conference, Pskov. April 15-20, 2002. Abstracts and Reports]. Moscow, Gosudarstvennyy istoricheskiy muzey, 2002, pp. 76-79. (In Russian)

20. Severova M.B. O nekotorykh monetakh Nogaya [On some coins of Noghai]. Tret'ya Vserossiyskaya Numizmaticheskaya konferentsiya $v$ g. Vladimire. 17-21 aprelya 1995 g. Tezisy dokladov [Third All-Russian Numismatic Conference in Vladimir. April, 17-21, 1995, Abstracts]. Moscow, Gosudarstvennyy istoricheskiy muzey, 1995, pp. 17-19. (In Russian)

21. Tizengauzen V.G. Sbornik materialov, otnosyashchikhsya k istorii Zolotoy Ordy. Vol. 1: Izvlecheniya iz arabskikh istochnikov [The Collection of Materials Related to the 
History of the Golden Horde. Vol. 1: Excerpts from Arabic Sources]. St. Petersburg, Imperatorskaya akademiya nauk, 1884. 563 p. (In Russian)

22. Uzelac A. Pod senkom psa - Tatari i južnoslovenske zemlje u drugoj polovini XIII veka [Under the Shadow of the Dog - Tatars and South Slavic Lands in the Second Half of the Thirteenth Century]. Beograd, Utopija, 2015. 321 p. (In Serbian)

23. Uzelac A. Serbskie pis'mennye istochniki o tatarah i Zolotoj Orde (pervaja polovina XIV v.) [Serbian Written Sources about Tatars and the Golden Horde (First Half of the Fourteenth Century)]. Zolotoordynskoe obozrenie=Golden Horde Review. Kazan, Sh.Marjani Institute of History of Tatarstan Academy of Sciences Publ., 2014, no. 1, pp. 101-118. (In Russian)

24. Hautala R. Pis'mo Ladislava, franciskanskogo kustodija Gazarii (Kaffa, 10 aprelja 1287 goda) [A Letter of Ladizlaus, the Franciscan Custodian of Gazaria (Caffa, April 10, 1287)]. Zolotoordynskoe obozrenie=Golden Horde Review. Kazan, Sh.Marjani Institute of History of Tatarstan Academy of Sciences Publ., 2017, Vol. 5, no. 1, pp. 193-199. (In Russian)

25. Benedetto L.F. (ed.). The Travels of Marco Polo, trans. A. Ricci. London, G. Routledge \& Sons, 1931, 439 p.

26. Bromberg J. Toponymical and Historical Miscellanies on Medieval Dobrudja, Bessarabia and Moldo-Wallachia. Byzantion, 1937, no. 12, pp. 151-180.

27. Burger G. Armenian Cilician Métissage and Hetoum's 'La Fleur des Histoires de la Terre d'Orient'. The Postcolonial Middle Ages, ed. J. Jerome Cohen. New York, Palgrave MacMillan, 2001, pp. 67-83. (In French)

28. Ciocîltan V. The Mongols and the Black Sea Trade in the Thirteenth and Fourteenth Centuries. Leiden-Boston, Brill, 2012. 344 p.

29. Dawson C. (ed.). The Mongol Mission: Narratives and Letters of the Franciscan Missionaries in Mongolia and China in the thirteenth and fourteenth centuries, New York: Sheed \& Ward, 1955. 246 p.

30. Failler A. Chronologie et composition dans l'Histoire de Georges Pachymère. Revue des études byzantines, 1990, no. 48, pp. 5-87. (In French)

31. Georges Pachymérès. Relations Historiques. Vol. 3, ed. A. Failler. Paris, Institut français d'études byzantines, 1999. 305 p. (In French)

32. Golubovich G. Biblioteca Bio-Bibliografica della Terra Santa e dell'Oriente Francescano, Vol. 2. Quaracchi-Firenze, Collegio di S. Bonaventura, 1913. 641 p. (In Italian, Latin)

33. Golubovich G. Biblioteca Bio-Bibliografica della Terra Santa e dell'Oriente Francescano, Vol. 3. Quaracchi-Firenze, Collegio di S. Bonaventura, 1919. 496 p. (In Italian, Latin)

34. Gossen C.T. Marco Polo und Rustichello da Pisa. Philologica Romanica Erhard Lommatzsch gewidmet, eds. M. Bambeck \& H.H. Christmann. München, Fink, 1975, pp. 133-143. (In German)

35. Hautala R. Latin Sources on the Religious Situation in the Golden Horde. Zolotoordynskoe obozrenie=Golden Horde Review. Kazan, Sh.Marjani Institute of History of Tatarstan Academy of Sciences Publ., 2016, Vol. 4, no. 2, pp. 336-346.

36. Hayton. La Flor des Estoires de la terre d'Orient / Flos Historiarum Terre Orientis, ed. Ch. Kohler, Recueil des Historiens des Croisades: Historiens Armeniens, II. Paris, Imprimerie nationale, 1906, pp. 111-363. (In French, Latin)

37. Herriott J.H. The 'Lost' Toledo Manuscript of Marco Polo. Speculum, 1937, Vol. 12, no. 4, pp. 456-463.

38. Jackson P. Marco Polo and his Travels. Bulletin of the School of Oriental and African Studies, 1998, Vol. 61, no. 1, pp. 82-101.

39. Kovacs Sz. A Franciscan Friar's Letter from the Crimea (1287). Acta Orientalia Academiae Scientiarum Hungaricae, Vol. 69, no. 2, pp. 157-164. 
40. Krumbacher K. Geschichte der Byzantinischen Litteratur von Justinian bis zum Ende des Oströmischen Reiches (527-1453). München, C.H. Beck, 1897. 1193 p. (In German)

41. Marco Polo. Il Milione, ed. D. Olivieri. Bari, 1928. 296 p. (In Italian)

42. Marco Polo. The Description of the World. Vol. 2, eds. A.C. Moule, P. Pelliot. London, Routledge \& Sons, 1935. 596 p.

43. Oberländer-Târnoveanu E. Numismatical Contributions to the History of SouthEastern Europe at the end of the $13^{\text {th }}$ Century. Revue Roumaine d'Histoire, 1987, no. 26, pp. 245-258.

44. Santoliquido V. I segmenti storico-militari nel Devisement dou monde di Marco Polo: analisi morfologica. Quaderni Veneti, 2015, Vol. 4, no. 2, pp. 157-187. (In Italian)

45. Schein S. 'Gesta Dei per Mongolos': The Genesis of a Non-Event. The English Historical Review, 1979, no. 94, pp. 805-819.

46. Spinei V. Les Mongols dans Historia Ecclesiastica Nova de Tholomeus de Lucca. Archivum Eurasiae Medii Aevi, 2011, no. 18, pp. 271-333. (In French)

47. Spuler B. Die Goldene Horde. Die Mongolen in Russland. Wiesbaden, Otto Harrassowitz, 1965. 638 p. (In German)

48. Tholomeus von Lucca. Die Annalen des Tholomeus von Lucca in doppelter Fassung nebst Teilen der Gesta Florentinorum und Gesta Lucanorum, ed. B. Schmeidler, Scriptores Rerum germanicarum, Nova Series VIII. Berlin, 1930. 379 p. (In German, Latin)

49. Tholomeus von Lucca. Historia ecclesiastica nova Nebst Fortsetzungen Bis 1329, ed. O. Clavuot, Monumenta Germaniae Historica, Scriptores, Vol. 39. Hannover, 2009. 784 p. (In German, Latin)

50. Uzelac A. War and Peace in the Pontic Steppes (1300-1302). Zolotoordynskoe obozrenie $=$ Golden Horde Review. Kazan, Sh.Marjani Institute of History of Tatarstan Academy of Sciences Publ., 2015, no. 2, pp. 65-80.

51. Vasary I. Cumans and Tatars - Oriental Military in the Pre-Ottoman Balkans, 1185-1365. Cambridge, Cambridge University Press, 2005. 230 p. $462 \mathrm{p}$.

52. Vernadsky G. The Mongols and Russia. New Haven, Yale University Press, 1953.

53. Van den Wyngaert A. Sinica Franciscana. Vol. 1: Itinera et relationes fratrum minorum saeculi XIII et XIV. Quaracchi-Firenze, 1929. 637 p. (In Latin)

54. Yule H., Cordier A. (eds.). Cathay and the Way Thither; being a collection of medieval notices of China, Vol. 3. London, Hakluyt Society, 1916. 269 p.

About the author: Aleksandar Uzelac - Ph.D. (History), Research Associate, The Institute of History Belgrade, ORCID: http://orcid.org/0000-0003-0626-2928 (36/II Kneza Mihaila Str., 11000 Belgrade, Serbia). E-mail: aleksandar.uzelac@iib.ac.rs 
Aleksandar Uzelac. Echoes of the Conflict between Tokhta and Nogai...

\title{
ЭХО КОНФЛИКТА МЕЖДУ ТОКТОЙ И НОГАЕМ В ХРИСТИАНСКОМ МИРЕ
}

\author{
Александар Узелац \\ Институт истории (Белград) \\ Белград, Сербия \\ aleksandar.uzelac@iib.ac.rs
}

\begin{abstract}
Цель исследования: статья посвящена анализу отображений войны (1297-1300 гг.) между ханом Токтой и его старшим кузеном Ногаем в христианском мире. Кроме предоставления общего обзора конфликта, его политического фона, военных действий и географического расположения, текст посвящен различным европейским и христианским синхронным источникам, в которых уделялось должное внимание этой войне. Хотя эти источники содержат лишь фрагментарные известия о конфликте, они дают возможность критически оценить, как христиане-современники воспринимали бурные события в Понтийских степях, и насколько они с ними были знакомы.

Материалы исследования: синхронные источники, в основном тексты, написанные византийским историком Георгием Пахимером, сербским архиепископом Данило II, итальянским клириком Бартоломео Фиадони, его соотечественником францисканцем Иоанном Монтекорвино, натурализованным французом армянского происхождения Хетумом из Корикоса (Хетум Патмич), а также венецианским путешественником Марко Поло.

Результаты и научная новизна: анализ источников показывает, что они, несмотря на разное происхождение их авторов, содержат некоторые общие черты относительно турбулентных событий в Золотой Орде. На основе их сообщений можно сделать вывод, что ключевые моменты и основные события этой войны, оказавшей сильное влияние на историю Золотой Орды, а также ее последствия, были хорошо известны на Балканах и в несколько меньшей степени в Западной Европе. Более того, они показывают, что слухи об этих событиях достигли самых отдаленных частей христианского мира.
\end{abstract}

Ключевые слова: Ногай, Токта, христианский мир, Георгий Пахимер, архиепископ Данило II, Бартоломео Фиадони (Птоломей из Лукки), Марко Поло, 13-14 века

Для цитирования: Uzelac A. Echoes of the Conflict between Tokhta and Nogai in the Christian World // Золотоордынское обозрение. 2017. Т. 5, № 3. C. 509-521. DOI: $10.22378 / 2313-6197.2017-5-3.509-521$

Сведения об авторе: Александар Узелац - Ph.D. (история), научный сотрудник, Институт истории (Белград), ORCID: http://orcid.org/0000-0003-0626-2928 (ул. Кнеза Михаила, 36/II, 11000 Белград, Сербия). E-mail: aleksandar.uzelac@iib.ac.rs 